\title{
PLASTIC INGESTION BY FLESH-FOOTED SHEARWATERS, PUFFINUS CARNEIPES, AND WEDGE-TAILED SHEARWATERS, PUFFINUS PACIFICUS
}

\author{
by Ian Hutton, Nicholas Carlile and David Priddel
}

(with two text-figures)

\begin{abstract}
Hutton, I., Carlile, N. \& Priddel, D. 2008 (31:x): Plastic ingestion by Flesh-footed Shearwaters, Puffinus carneipes, and Wedge-tailed Shearwaters, Puffinus pacificus. Papers and Proceedings of the Royal Society of Tasmania 142(1): 67-72. https://doi.org/10.26749/rstpp.142.1.67 ISSN 0080-4703. Lord Howe Island Tours, PO Box 157, Lord Howe Island, NSW 2898, Australia (IH*), Department of Environment and Clinate Change (NSW), PO Box 1967, Hurstville, NSW 2220, Australia (NC, DP).*Author for correspondence. Email: ianhutton@clearmail.com.au
\end{abstract}

\begin{abstract}
The population of Flesh-footed Shearwaters, Puffinus carneipes, on Lord Howe Island, Australia, has decreased over recent decades. Known threats include long-line fishing and loss of nesting habitat. The recent occurrence of plastic debris in breeding colonies has raised concerns that plastic ingestion also may be contributing to the decline of this species. In this paper we investigate the extent of plastic ingestion by Flesh-footed and Wedge-tailed shearwaters, Puffinuspacificus, on Lord Howe Island. The remains of failed Flesh-footed Shearwater fledglings contained substantial quantities of plastics: up to $37 \mathrm{~cm}^{3}$, equivalent to at least $31 \%$ of proventricular capacity. Road-killed adults $(\mathrm{n}=$ 21) had no plastic in their provenrriculus. Proventricular contents of near-fledged birds, obtained by non-lethal means, showed that $79 \%$ of Flesh-footed Shearwaters and $43 \%$ of Wedge-tailed Shearwaters contained plastics, in volumes of up to $18.0 \mathrm{~cm}^{3}$ and $2.8 \mathrm{~cm}^{3}$, respectively. Plastic loads were significantly less in Wedge-tailed Shearwaters, the difference possibly due to different densities of plastic within the foraging locations of each species. The impact of plastic ingestion on the survival of Flesh-footed Shearwater chicks and fledglings, and the consequent impacts on the demography of the population are unknown and warrant further investigation.
\end{abstract}

Key Words: marine pollution, marine litter, Lord Howe Island, Wedge-tailed Shearwater, plastic ingestion, Flesh-footed Shearwater, Puffinus carneipes, Puffinus pacificus.

\section{INTRODUCTION}

The Flesh-footed Shearwater, Puffinus carneipes Gould, 1844, is a pelagic seabird that breeds in dense colonies on islands in New Zealand and in southwestern Australia, as well as on St Paul and Lord Howe islands (Fullagar et al. 1974, Roux 1985, Ross et al. 1996, Taylor 2000). The species is a trans-equatorial migrant that winters on both sides of the North Pacific Basin (Marchant \& Higgins 1990). The population of Flesh-footed Shearwaters on Lord Howe Island, estimated to be approximately 17500 pairs, has decreased substantially during the past few decades (Priddel et al. 2006). Known causes of decline include mortality in long-line fishing (Baker \& Wise 2005) and loss of nesting habitat (Priddel et al. 2006). Recent observations of skeletal remains containingsizableamounts of plastic, together with plastic debris scattered throughout the breeding colonies of the Flesh-footed Shearwater, raised concerns that plastic ingestion may also be contributing to the decline of this species (Hutton 2004). In this paper we investigate the prevalence of plastic ingestion by Flesh-footed and Wedgetailed shearwaters, Puffinus pacificus (J.F. Gmelin, 1789), on Lord Howe Island. These two species breed concurrently during the Austral summer with eggs of both species typically laid in late November or early December and young fledging in late April and May (Fullagar et al. 1974, Priddel et al. 2006). Both species feed on, or close to, the surface, although Flesh-footed Shearwaters can also dive deeply. The Wedge-tailed Shearwater is common throughout the tropical and sub-tropical waters of both the Pacific and Indian oceans. The current size of the population on Lord Howe Island is not known; the most recent estimate, in 1972 , suggested there were approximately 30000 pairs (Fullagar et al. 1974).
Many species of seabirds are particularly susceptible to plastics in the marine environment. Small pieces of plastic floating on or near the surface of the ocean can resemble the adults and larvae of crustaceans (Mauchline 1980, Raymont 1983) or may harbour the eggs of pelagic fish (Colton et al. 1974). Consequently, seabirds mistake plastic for food and ingest it, sometimes in large quantities (Moser \& Lee 1992, Laist 1997). Plastic ingestion has a range of lethal and sub-lethal consequences. By decreasing the capacity of the proventriculus, the accumulated plastic can lower food intake, resulting in lower fledging mass and decreased survival (Connors \& Smith 1982, Ryan 1987a, Sievert \& Sileo 1993). Plastics can impair gastrointestinal function or cause physical damage to the bird's gastrointestinal tract, including perforation, blockage or ulceration (Day 1980, Pettit et al. 1981, Zonfrillo 1985, Fry et al. 1987, Pierce et al. 2004). Also, during digestion plastic can release toxins such as polychlorinated biphenyls (Ryan et al. 1988), which can accumulate in the tissues of the bird causing impaired fitness and reduced survival (Pettit et al. 1981, van Franeker 1985). These, and other toxins, can also disrupt reproduction by lowering steroid hormone levels and delaying ovulation (Peakall 1970, Hoffman et al. 1996).

Adults of many species of seabirds habitually regurgitate indigestible parts of their food, such as squid beaks, fish bones and plastic (e.g., Hays \& Cormons 1974). Chicks, however, tend not to regurgitate until they are almost fully fledged, so plastics accumulate in their gut during the nestling period. For both Flesh-footed and Wedge-tailed shearwaters this period is about 14 weeks (Roberts et al. 1975, Powell et al. 2007). The low propensity of chicks to regurgitate indigestible material places them at greater risk than adults. The physical presence of plastic in the gut not only prevents chicks from receiving a full load of food at each feed, but by 
preventing proventricular contraction - an important cue in the stimulation of hunger - they may have depressed appetite and diminished feeding activity (Sturkie 1965, Connors \& Smith 1982, Ryan 1988a). The lower nutrient intake may result in reduced fitness or death, often through dehydration (Sievert \& Sileo 1993).

Despite these consequences, definitive evidence of death or physiological damage resulting from plastic ingestion is difficult to obtain (Auman et al. 1998), with comparative studies often failing to reach statistical significance because of small sample sizes (Day 1980, Connors \& Smith 1982). Additionally, proving cause and effect is problematic because of the difficulty in isolating this particular factor (Ryan 1987a). In this study, we aim only to determine the extent of plastic ingestion in two species of shearwater, not its impacts.

\section{STUDY SITE}

Lord Howe Island $\left(31^{\circ} 30^{\prime} \mathrm{S}, 159^{\circ} 05^{\prime} \mathrm{E}\right)$ is a small ( $1455 \mathrm{ha}$ ) oceanic island in the South Pacific Ocean, $580 \mathrm{~km}$ east of the Australian mainland. An area of lowlands, much of which has been cleared for agriculture and settlement, separates the northern hills $(209 \mathrm{~m})$ from the two southern mountains $(875 \mathrm{~m})$. The main island is surrounded by a number of smaller islets and rocks. Flesh-footed Shearwaters nest on the main island at several locations within the lowlands, on calcarenite soils, in burrows up to $3.4 \mathrm{~m}$ long (Priddel et al. 2006). Wedge-tailed Shearwaters are more abundant, and their nesting grounds are more dispersed. They breed at numerous sites on the coastal fringe of the main island and on most of the smaller islets within the group.

\section{METHODS}

Periodically, between October 2001 and August 2002, the colony of Flesh-footed Shearwaters near Neds Beach (see Priddel et al. 2006) was searched for the remains of dead shearwaters. Carcasses were collected and dissected. Any plastics were separated from the skeletal material and other remains. The number of pieces and approximate size of each piece were recorded. The plastic recovered from each bird was then submerged under water in a graduated flask and its volume determined (to the nearest $0.1 \mathrm{~cm}^{3}$ ) by displacement. Small, trace amounts were recorded as $0.1 \mathrm{~cm}^{3}$.

During 27-29 April 2005, Flesh-footed Shearwater colonies were searched at night to capture and sample live, near-fledged birds on the surface. These birds were approximately 13-14 weeks old and, judging from the development of their primaries, were about 1-10 days from fledging. We sampled the stomach contents of 56 birds by flushing the proventriculus with water, as described by Wilson (1984). This non-lethal technique generally recovers $89-100 \%$ of the proventricular contents (Ryan \& Jackson 1986), so some plastic fragments may remain in the gut (Sileo et al. 1990). In an attempt to recover the entire stomach contents, each bird was flushed three times. The maximum volume of water pumped into the bird before it regurgitated was tecorded and used to approximate the maximum capacity of the proventriculus. All regurgitated material was collected. The quantities of water and oil were measured using a graduated flask and then discarded. Any plastic or other solid material was retained and sorted.
The volume of this material was later measured by water displacement. Moribund or malformed birds that were incapable of flight were flushed and then euthanased. These birds, together with any carcasses found, were dissected and the contents of the proventriculus removed, sorted and measured.

Between late April and early May 2005, Flesh-footed Shearwater colonies were searched by day to collect freshly dead birds $(n=6)$ and regurgitated boluses $(n=124)$ containing plastic and other indigestible material. Boluses were collected only if fresh (i.e., the mucus in them was still wet). The volumes of plastics and other solid material were measured as described above.

Flesh-footed Shearwaters found killed on the roads between 2001 and 2007 were collected and stored frozen. These were subsequently thawed and dissected. The contents of the proventriculus were removed and the volume of plastic was measured.

On 29 April 2005, 30 near-fledged Wedge-tailed Shearwater chicks were extracted from their burrows and their proventriculat contents sampled using the methods described above. Judging ftom the development of their primaries, these birds were approximately $2-3$ weeks from fledging. After all fledglings had departed the colony, the nesting area was searched to locate the remains of dead chicks and regurgitated boluses of plastic and other indigestible material.

\section{Statistical analyses}

Single-factor ANOVAs were used to examine differences in (1) the mean quantities of plastic in live and dead Fleshfooted Shearwater chicks, (2) the quantity of plastic in chicks and in boluses, and (3) the amount of plastic and other indigestible material. Differences in the quantity of plastic flushed from the two species of shearwater were examined by single-factor ANOVA, after data were log-transformed to normalise variances. All means are given \pm SD.

\section{RESULTS}

\section{Flesh-footed Shearwaters}

The skeletal remains of 14 Flesh-footed Shearwaters were found in the area searched during 2001-02. All these remains contained plastic, in volumes ranging from $10-37 \mathrm{~cm}^{3}$ (mean $20.5 \pm 7.1 \mathrm{~cm}^{3}$ ). In total, 579 pieces of plastic were recovered from these 14 birds, an average of 41 pieces per individual. The pieces were predominantly flat fragments of containers and other articles that ranged in size from about $25 \mathrm{~mm}^{2}$ to $1500 \mathrm{~mm}^{2}$; with a median size of about $30 \times 20$ $\mathrm{mm}$. Identifiable plastic items in carcasses included bottle, carton or tube caps (16), bag or balloon ties (5), strapping tape (2), a golf tee (1) and a pen top (1).

Of the 56 near-fledged Flesh-footed Shearwater chicks sampled during 2005, 44 (79\%) contained plastic (mean 2.6 $\pm 3.6 \mathrm{~cm}^{3}$; range $0.1-18.0 \mathrm{~cm}^{3}$, fig. 1). Forty-one birds (73\%) contained oil, in volumes ranging from $0.5-38.5 \mathrm{ml}$ (mean $9.9 \pm 9.1 \mathrm{ml}$ ). Thirty-one birds $(55 \%)$ contained other solids (squid beaks, otoliths, pumice and fish bones) in volumes ranging from $0.1-5.0 \mathrm{~cm}^{3}$ (mean $\left.0.7 \pm 1.0 \mathrm{~cm}^{3}\right)$. Maximum proventriculus volume was $120 \mathrm{ml}$. For birds that contained some indigestible material, the mean quantity of plastic in the proventriculus exceeded the total amount of other solid 


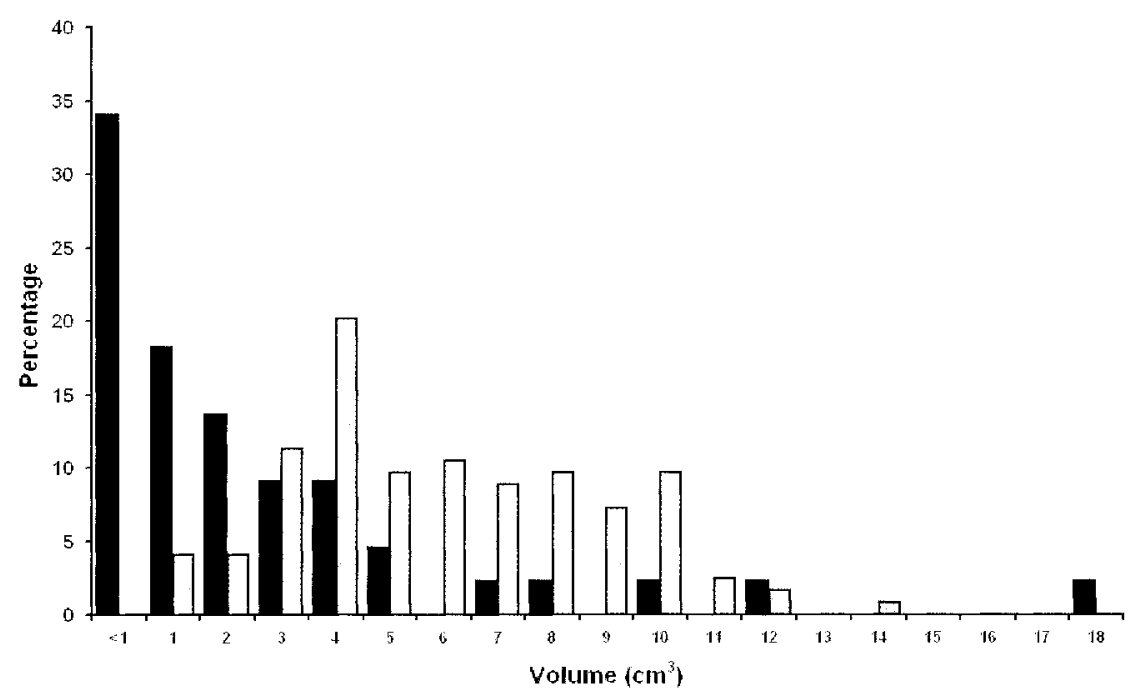

FIG. 1 - Frequency distribution of the volume of plastic contained in the proventriculi of near-fledged Flesh-footed Shearwater chicks (solid bars) and in regurgitated boluses of indigestible material (light bars). Data include only those birds $(n=44)$ and boluses $(n=124)$ that contained plastic.

material (ANOVA, F1, $73=8.635, P<0.004$ ).

One of the 56 birds sampled had malformed wings and, although it was otherwise healthy, it was unable to fly, and so was euthanased. The proventricular contents of this bird obtained by flushing consisted of one squid beak $(0.1$ $\left.\mathrm{cm}^{3}\right)$ and one plastic bead $\left(0.1 \mathrm{~cm}^{3}\right)$. Necropsy found the proventriculus to be empty indicating that all proventricular contents had been removed by flushing. Another two individuals were moribund when found; these birds were flushed but were omitted from the sample of 56 above because they were clearly unwell and may not have been feeding normally. Both were euthanased. Flushing yielded 20 small pieces of plastic $\left(1.6 \mathrm{~cm}^{3}\right)$ and a small amount of other solids $\left(0.1 \mathrm{~cm}^{3}\right)$ from one bird, and nothing from the other. Necropsy found one additional piece of plastic $(0.1$ $\mathrm{cm}^{3}$ ) in the proventriculus of the first bird and nothing in the second, indicating that flushing removed $94 \%$ of the proventricular contents.

Six other near-fledged chicks from the 2005 cohort were found dead. Necropsy revealed that each bird contained significant quantities of plastic (mean $24.5 \pm 5.0 \mathrm{~cm}^{3}$, range $\left.18-32 \mathrm{~cm}^{3}\right)$. Dead birds contained significantly more plastic than did live birds (ANOVA, F1, $48=178.9$, $P<0.0001$ ).

All 124 freshly regurgitated boluses that were collected contained plastic (mean $5.8 \pm 2.8 \mathrm{~cm}^{3}$; range $1.0-14.0 \mathrm{~cm}^{3}$, fig.1) and small amounts of other indigestible solids. All boluses also contained various amounts of down, indicating they had been regurgitated by chicks, and consistent with observations that most adults had departed the colony by this time. The mean quantity of plastic in each bolus exceeded the mean amount of plastic flushed from each bird (ANOVA, F1, $166=36.887, P<0.0001$; birds without plastic were excluded).

A total of 21 adult Flesh-footed Shearwaters were found dead on the road after having been killed by vehicles. No plastic was found in any of these birds.

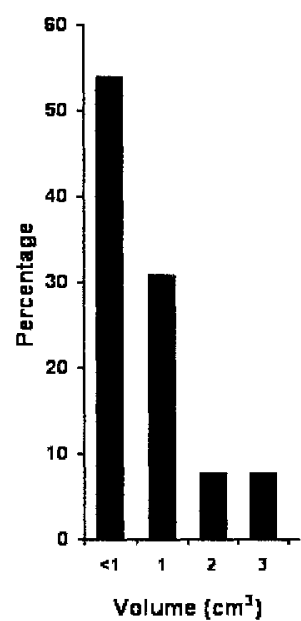

FIG. 2 - Frequency distribution of the volume of plastic contained in the proventriculi of near-fledged Wedge-tailed Shearwater chicks. Data include only those birds $(n=13)$ that contained plastic.

\section{Wedge-tailed Shearwaters}

Of 30 Wedge-tailed Shearwater chicks sampled for proventricular contents during 2005, 13 (43\%) contained plastics (mean $0.7 \pm 0.9 \mathrm{~cm}^{3}$; range $0.1-2.8 \mathrm{~cm}^{3}$, fig. 2). Ten birds (33\%) contained other indigestible material (fish bones, squid beaks, pumice and wood) in volumes ranging from $0.1-4.5 \mathrm{~cm}^{3}$ (mean $\left.2.0 \pm 1.2 \mathrm{~cm}^{3}\right)$. All birds contained varying amounts of fish and squid, but none contained oil. Maximum proventricular volume was $90 \mathrm{ml}$. The quantity of plastic found in Wedge-tailed Shearwater chicks was less than that recovered from Flesh-footed Shearwater chicks (ANOVA, $\mathrm{F} 1_{53}=4.541, P=0.038$, figs 1 and 2 ).

Of 22 Wedge-tailed Shearwater carcasses found in the colony, three (14\%) contained plastic $\left(1.5 \mathrm{~cm}^{3}, 5.0 \mathrm{~cm}^{3}\right.$ and $\left.11.0 \mathrm{~cm}^{3}\right)$. No boluses of regurgitated plastic were found during searches of Wedge-tailed Shearwater colonies. 


\section{DISCUSSION}

This study has shown that both Flesh-footed and Wedge-tailed shearwaters breeding on Lord Howe Island ingest plastic. Plastic ingestion was particularly prevalent among Fleshfooted Shearwaters, and many unsuccessful fledglings had died with substantial amounts of plastic in their proventriculus. The highest plastic load $\left(37 \mathrm{~cm}^{3}\right)$ was equivalent to $31 \%$ of proventricular capacity of the largest individual. Based on these observations we speculate that some Flesh-footed Shearwater chicks probably died as a result of excessive quantities of ingested plastic. However, we know of only one instance where death of a chick can be directly attributed to ingested plastic. Necropsy of this chick, found dead in 2005, revealed that the proventriculus had been punctured by a sharp piece of plastic (S. Thalmann pers. comm.).

Seventy-nine per cent of near-fledged Flesh-footed Shearwater chicks on Lord Howe Island contained plastic. The quantity of plastic recovered from live chicks was highly variable, but generally was less than that recovered from dead chicks: whereas $50 \%$ of dead birds contained $>5 \mathrm{~cm}^{3}$ of plastic, only $10 \%$ of live birds contained this amount. It is possible that flushing failed to remove all plastic from the proventriculus, thus accounting for the apparent difference in plastic loads between live and dead birds. However, evidence from the small number of birds that were both flushed and necropsied indicated that less than $6 \%$ of items remained in the proventriculus after flushing.

The appearance of numerous boluses containing regurgitated plastic throughout the Flesh-footed Shearwater colonies in May of each year, after most adults had left, indicated that many fledglings offloaded the plastic that had accumulated in their gut before they departed from the island. The amount of plastic recovered from live birds was less than that contained in these boluses and it is likely that many of the birds sampled had already regurgitated some plastic. We conclude that plastic ingested by Fleshfooted Shearwater chicks accumulates in the proventriculus until shortly before fledging, when the young emerge from their burrows and regurgitate their proventricular contents, presumably in preparation for flight. The absence of plastic in adults indicates that these birds expel any plastic they ingest, at least some of it being passed onto their offspring.

Although $43 \%$ of Wedge-tailed Shearwater chicks on Lord Howe Island contained plastic, plastic ingestion was much less of a problem for this species (see figs 1 and 2), at least during the period of this study. Compared to Flesh-footed Shearwater chicks of approximately the same age, (i) fewer individuals contained plastic, (ii) lesser quantities of plastic were present in the proventriculus of those birds affected, and (iii) boluses containing plastic were not obvious in the colony. The reasons for these species-related differences are unclear. Although the feeding behaviour of the two species differs, Wedge-tailed Shearwaters tend to forage closer to the surface than do Flesh-footed Shearwaters and thus would be more, rather than less, likely to encounter floating plastics. It is possible that Wedge-tailed Shearwaters are much more selective in the items that they pick up, but a more likely explanation is that they forage in areas where there are lower concentrations of plastics. Proventricular oil was found in $73 \%$ of the Flesh-footed Shearwater chicks sampled, but in none of the Wedge-tailed Shearwater chicks. This difference reflects dissimilarity in the foraging range of the two species, with Flesh-footed Shearwaters probably travelling further from Lord Howe Island than do Wedge-tailed Shearwaters (Schultz \& Klomp 2000). During winter, Wedge-tailed Shearwaters forage at much lower latitudes in the North Pacific than do Flesh-footed Shearwaters (Marchant \& Higgins 1990) and species that winter in the tropics tend to have much lower plastic loads than those that winter further north, presumably because the density of plastic in the tropical Pacific is lower than in the North Pacific (Spear et al. 1995). Although plastics are ubiquitous throughout all the oceans of the world (Derraik 2002), variability in ocean circulation patterns can change the amount of marine debris regionally and therefore the amount available to seabirds foraging in a particular area (e.g., Morishige et al. 2007).

The high incidence of plastic in Flesh-footed Shearwater chicks on Lord Howe Island was not unusual for this species or other congeners. Of 83 Flesh-footed Shearwaters killed in driftnet fisheries in the North Pacific during 1990-91, 79 (95\%) contained ingested plastic (Robards et al. 1997). In the same study, the incidence of plastic ingestion was $85 \%(\mathrm{n}=543)$ for Sooty Shearwaters, Puffinus griseus (J.F. Gmelin, 1789), and $88 \%(\mathrm{n}=200)$ for Short-tailed Shearwaters, $P$. tenuirostris (Temminck, 1835). A similar study by Ogi (1990) found comparable levels of plastic ingestion: $89 \%(\mathrm{n}=193)$ for Sooty Shearwaters and 82\% $(n=265)$ for Short-tailed Shearwaters. Reported incidences of plastic ingestion by Wedge-tailed Shearwaters, although highly variable, have been somewhat lower: 3-29\% (Sileo et al. 1990); 12-60\% (Spear et al. 1995); 60\% (Fry et al. 1987 ); $43 \%$ (this study).

From a sample of Wedge-tailed Shearwaters shot at sea in the central Pacific between 1984 and 1991 Spear et al. (1995) found the incidence of plastic varied among age classes: $20 \%$ of fledglings, $60 \%$ of pre-breeding adults and $12 \%$ of postbreeding adults contained plastic. The relative incidence of plastic in each age class is consistent with our interpretation of data obtained from Flesh-footed Shearwaters on Lord Howe Island, i.e., plastic, much of which is picked up at the winter foraging grounds, is offloaded to chicks by adults and then offloaded by chicks via boluses prior to fledging. Ryan \& Jackson (1987) and Ryan (1988b) also reported lighter plastic loads in adults after the breeding season compared to before it, and suggested that offloading of plastics by parents to young accounted for this difference. Spear et al. (1995) argued that the low incidence of plastic in fledglings at sea offered little evidence to support this hypothesis, but these authors failed to take into account that, as shown in this study, many fledglings purge themselves of plastic before departing from the breeding grounds.

On Lord Howe Island Flesh-footed Shearwaters breed among human habitation, so the absence of any previous local record of plastic ingestion by this species suggests that this phenomenon may have become more prevalent in recent years. Other studies, however, have shown that the level of plastic ingestion can vary dramatically between years (Ryan 1988b, Sileo et al. 1990). For example, plastic was present in 44\% of Red-tailed Tropicbird, Phaethon rubricauda Boddaert, 1783, chicks at Midway Atoll, Northwestern Hawaiian Islands, in 1986 but in only 2\% of chicks the following year (Sileo et al. 1990). Similarly, the mean volume of plastic ingested by Laysan Albatross, Phoebastria immutabilis (Rothschild, 1893), chicks in consecutive years was $46 \mathrm{~cm}^{3}$ and $5 \mathrm{~cm}^{3}$ (Sileo et al. 1990). Further studies are needed to assess the long-term trends in plastic ingestion by Flesh-footed Shearwaters on Lord Howe Island. 
Although the incidence of plastic varies considerably both among species and among individuals within species (Furness 1985, Azzarello \& Van Vleet 1987, Ryan 1987b, Moser \& Lee 1992, Spear et al. 1995) the growing body of evidence suggests that the frequency and quantity of ingested plastic in seabirds is increasing (Robards et al. 1997). More than one-third of the world's seabird species are now known to ingest plastic, with Procellariiformes being among those most affected (63\% of species, Laist 1997). In many species, the proportion of individuals that contain plastic exceeds $80 \%$. This increase in plastic ingestion parallels an observed increase in plastic pollution in the areas where many seabirds forage (Moser \& Lee 1992). The increase in plastic ingestion in seabirds is a disturbing trend, particularly as this is only one of a number of anthropogenic threats affecting these species (Baker et al. 2002). Long-line fishing and loss of nesting habitat have both been identified as serious threats to the population of Flesh-footed Shearwater on Lord Howe Island (Baker \& Wise 2005, Priddel et al. 2006). The threatened status of this population warrants further studies be undertaken to monitor population size, along with experimental research or modelling to assess the impact of plastic ingestion on chick and fledgling survival.

Many countries have taken comprehensive action to address the issue of marine litter through legislation, enforcement of international agreements, provision of reception facilities for ship-generated wastes, adoption of improved practices for the disposal of waste on land, and support for extensive beach clean-up activities, as well as information, education and public awareness programs (UNEP 2005). Despite these efforts, the situation, globally as well as regionally, is worsening; the quantity of plastic waste circulating in the world's oceans continues to grow (Derraik 2002). It is clear that the problem cannot be solved solely by means of legislation, law enforcement and technical solutions, it is also a cultural problem that requires changes to attitudes, behaviours and management approaches (UNEP 2005).

\section{ACKNOWLEDGEMENTS}

This study was conducted with support from the Lord Howe Island Board. Sam Thalmann demonstrated to us the proventriculus-flushing technique used in this study. This work was carried out under DECC Animal Research Authority 021028 and NPWS Scientific Licences S10614 and $S 12161$.

\section{REFERENCES}

Auman, H.J., Ludwig, J.P., Giesy, J.P. \& Colborn, T. 1998: Plastic ingestion by Laysan Albatross chicks on Sand Island, Midway Atoll, in 1994 and 1995. In Robertson, G. \& Gales, R. (eds): Albatross Biology and Conservation. Surrey Beatty and Sons, Chipping Norton: 239-244.

Azzarello, M.Y. \& Van Vleet, E.S. 1987: Marine birds and plastic pollution. Marine Ecology Progress Series 37: 295-303.

Baker, G.B., Gales, R., Hamilton, S. \& Wilkinson, V. 2002: Albatrosses and petrels in Australia: a review of their conservation and management. Emu 102: 71-97.

Baker, G.B. \& Wise, B.S. 2005: The impact of pelagic longline fishing on the Flesh-footed Shearwater Puffinus carneipes in Eastern Australia. Biological Conservation 126: 306-316.
Colton, J.B., Knapp, F.D. \& Burns, B.R. 1974: Plastic particles in surface waters of the northwestern Atlantic. Science 185: $491-497$.

Connors, P.G. \& Smith, K.G. 1982: Oceanic plastic particle pollution: suspected effect on fat deposition in Red Phalaropes. Marine Pollution Bulletin 13: 18-20.

Day, R.H. 1980: The occurrence and characteristics of plastic pollution in Alaska's marine birds. Unpublished M.S. thesis, University of Alaska.

Derraik, J.G.B. 2002: The pollution of the marine environment by plastic debris: a review. Marine Pollution Bulletin 44: 842-852.

Fry, D.M., Fefer, S.I. \& Sileo, L. 1987: Ingestion of plastic debris by Laysan Albatrosses and Wedge-tailed Shearwaters in the Hawaiian Islands. Marine Pollution Bulletin 18: 339-343.

Fullagar, P.J., McKean, J.L. \& van Tets, G.F. 1974: Appendix F. Report on the birds. In Recher, H.F. \& Clark, S.S. (eds): Environmental Survey of Lord Howe Island. New South Wales Government Printer, Sydney: 55-72.

Furness, R.W. 1985: Plastic particle pollution: accumulation by Procellariiform seabirds at Scottish colonies. Marine Pollution Bulletin 16: 103-106.

Hays, H. \& Cormons, G. 1974: Plastic particles found in tern pellets on coastal beaches and at factory sites. Marine Pollution Bulletin 5: 44-46.

Hoffman, D.J., Rice, C.P. \& Kubiak, T.J. 1996: PCBs and dioxins in birds. In Beyer, W.N., Heinz, G.H. \& RedmonNorwood, A.W. (eds): Environmental Contaminants in Wildife: Interpreting Tissue Concentrations. Lewis Publishers, New York: 165-207.

Hutton, I. 2004: Plastic perils for seabirds. Nature Australia 28: $52-59$.

Laist, D.W. 1997: Impacts of marine debris: entanglement of marine life in marine debris including a comprehensive list of species with entanglement and ingestion records. In Coe, J.M. \& Rodgers, D.B. (eds): Marine Debris: Sources, Impacts and Solutions. Springer-Verlag, New York: 99-139.

Marchant, S. \& Higgins, P.J. 1990: Handbook of Australian, New Zealand and Antarctic Birds. Volume I: Ratites to Ducks. Oxford University Press, Melbourne: $1400 \mathrm{pp}$.

Mauchline, J. 1980: The biology of mysids and euphausiids. Advances in Marine Biology 18: 1-681.

Morishige, C., Donohue, M., Flint, E., Swenson, C. \& Woolaway, C. 2007: Factors affecting marine debris deposition at French Frigate Shoals, Northwestern Hawaiian Islands Marine National Monument, 19902002. Marine Pollution Bulletin 54: 1162-1169.

Moser, M.L. \& Lee, D.S. 1992: A fourteen-year survey of plastic ingestion by western North Atlantic seabirds. Colonial Waterbirds 15: 83-94.

Ogi, H. 1990: Ingestion of plastic particles by sooty and shorttailed shearwaters in the North Pacific. In Shomura, R.S. \& Godfrey, M.L. (eds): Proceedings of the Second International Conference on Marine Debris, 2-7 April 1989, Honolulu, Hawaii. US Department of Commerce, Washington: 635-652.

Peakall, D.B. 1970: p,p'DDT: effect on Ca metabolism and concentration of estradiol in the blood. Science $\mathbf{1 6 8}$ : 592-594.

Pettit, T.N., Grant, G.S. \& Whittow, G.C. 1981: Ingestion of plastics by Laysan Albatross. Auk 98: 839-841.

Pierce, K.E., Harris, R.J., Larned, L.S. \& Pokras, M.A. 2004: Obstruction and starvation associated with plastic ingestion in a northern gannet Morus bassanus and a greater shearwater Puffinus gravis. Marine Ornithology 32: $187-189$.

Powell, C.D.L., Wooller, R.D. \& Bradley, J.S. 2007: Breeding biology of the Flesh-footed Shearwater (Puffinus carneipes) on Woody Island, Western Australia. Emu 
107: 275-283.

Priddel, D., Carlile, N., Fullagar, P., Hutton, I. \& O'Neill, L. 2006: Decline in the distribution and abundance of Flesh-footed Shearwaters (Puffinus carneipes) on Lord Howe Island, Australia. Biological Conservation 128: 412-424.

Raymont, J.E.G. 1983: Plankton and Productivity in the Oceans. Zooplankton, Vol 2, 2nd edition. Pergamon Press, New York: $824 \mathrm{pp}$.

Robards, M.D., Gould, P.J. \& Piatt, J.F. 1997: The highest global concentrations and increased abundance of oceanic plastic debris in the North Pacific: evidence from seabirds. In Coe, J.M. \& Rogers, D.B. (eds): Marine Debris. SpringerVerlag, New York, USA: 71-80.

Roberts, P.E., Merritt, F.D. \& Floyd, R.B. 1975: Wedge-tailed Shearwaters on Muttonbird Island, Coffs Harbour, NSW. Emu 75: 19-22.

Ross, G.J.B., Weaver, K. \& Grieg, J.C. 1996: The Status of Australia's Seabirds: Proceedings of the National Seabird Workshop, Canberra 1-2 November 1993. Biodiversity Group, Environment Australia, Canberra: 237 pp.

Roux, J.P. 1985: Le statut du puffin a pieds pales (Puffinus carneipes)

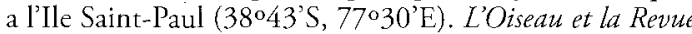
Francaise d'Ornithologie 55: 155-157.

Ryan, P.G. 1987a: The effects of ingested plastic on seabirds: Correlations between plastic loads and body condition. Environmental Pollution 46: 119-125.

Ryan, P.G. 1987b: The incidence and characteristics of plastic particles ingested by seabirds. Marine Environment Research 23: $175-206$

Ryan, P.G. 1988a: Effects of ingested plastic on seabird feeding: evidence from chickens. Marine Pollution Bulletin 19 $125-128$.

Ryan, P.G. 1988b: Intraspecific variation in plastic ingestion by seabirds and the flux of plastic through seabird populations. Condor 90: 446-452.

Ryan, P.G., Connell, A.D. \& Gardner, B.D. 1988: Plastic ingestion and PCBs in seabirds: is there a relationship? Marine Pollution Bulletin 19: 174-176.

Ryan, P.G. \& Jackson, S. 1986: Stomach pumping: is killing seabirds necessary? Auk 103: 427-428.
Ryan, P.G. \& Jackson, S. 1987: The lifespan of ingested plastic particles in seabirds and their effect on digestive efficiency. Marine Pollution Bulletin 18: 217-219.

Schultz, M.A. \& Klomp, N.I. 2000: Chick provisioning behaviour of two shearwaters breeding in south-eastern Australia. Austral Ecology 25: 319-326.

Sievert, P.R. \& Sileo, L. 1993: The effects of ingested plastic on growth and survival of albatross chicks. In Vermeer, K., Briggs, K.T., Morgan, K.H. \& Siegel-Causey, D. (eds): The Status, Ecology and Conservation of Marine Birds of the North Pacific. Canadian Wildlife Service Special Publication, Ottawa: 212-217.

Sileo, L., Sievert, P.R. \& Samuel, M.D. 1990: Prevalence and characteristics of plastic ingested by Hawaiian seabirds. In Shomura, R.S. \& Godfrey, M.L. (eds): Proceedings of the Second International Conference on Marine Debris, 2-7 April 1989, Honolulu, Hawaii. US Department of Commerce, Washington: 665-681.

Spear, L.B., Ainley, D.G. \& Ribic, C.A. 1995: Incidence of plastic in seabirds from the tropical Pacific, 1984-91: relation with distribution of species, sex, age, season, year and body weight. Marine Environmental Research 40: 123-146.

Sturkie, P.D. 1965: Avian Physiology. Cornell University Press, New York: $766 \mathrm{pp}$.

Taylor, G.A. 2000: Action Plan for Seabird Conservation in New Zealand. Part B: Non-threatened Seabirds. Threatened species occasional publication no. 17. Department of Conservation, Biodiversity Recovery Unit, Wellington: $201 \mathrm{pp}$.

UNEP 2005: Marine litter, an analytical overview. United Nations Environment Program, Nairobi: 47 pp.

van Franeker, J.A. 1985: Plastic ingestion in the North Atlantic Fulmar. Marine Pollution Bulletin 16: 367-369.

Wilson, R.P. 1984: An improved stomach pump for penguins and other seabirds. Journal of Field Ornithology 55: $109-112$.

Zonfrillo, B. 1985: Petrels eating contraceptives, polythene and plastic beads. British Birds 78: 350-351.

(accepted 24 May 2008) 